\title{
Phobos LIFE (Living Interplanetary Flight Experiment)
}

\author{
Bruce H. Betts, ${ }^{1}$ David Warmflash, ${ }^{1}$ Raymond E. Fraze, ${ }^{2,3}$ Louis Friedman, ${ }^{1}$ Elena Vorobyova, ${ }^{4,5}$ \\ Timothy G. Lilburn, ${ }^{6}$ Amy Smith, ${ }^{7}$ Petra Rettberg, ${ }^{8}$ K. Ingemar Jönsson, ${ }^{9}$ Neva Ciftcioglu, ${ }^{10}$ George E. Fox, ${ }^{11}$ \\ Tomas Svitek, ${ }^{2}$ Joseph L. Kirschvinck, ${ }^{12,13}$ Ralf Moeller, ${ }^{8}$ Marko Wassmann, ${ }^{14}$ and Thomas Berger ${ }^{8}$
}

\begin{abstract}
The Planetary Society's Phobos Living Interplanetary Flight Experiment (Phobos LIFE) flew in the sample return capsule of the Russian Federal Space Agency's Phobos Grunt mission and was to have been a test of one aspect of the hypothesis that life can move between nearby planets within ejected rocks. Although the Phobos Grunt mission failed, we present here the scientific and engineering design and motivation of the Phobos LIFE experiment to assist with the scientific and engineering design of similar future experiments. Phobos LIFE flew selected organisms in a simulated meteoroid. The 34-month voyage would have been the first such test to occur in the high-radiation environment outside the protection of Earth's magnetosphere for more than a few days. The patented Phobos LIFE "biomodule" is an $88 \mathrm{~g}$ cylinder consisting of a titanium outer shell, several types of redundant seals, and 31 individual Delrin sample containers. Phobos LIFE contained 10 different organisms, representing all three domains of life, and one soil sample. The organisms are all very well characterized, most with sequenced genomes. Most are extremophiles, and most have flown in low Earth orbit. Upon return from space, the health and characteristics of organisms were to have been compared with controls that remained on Earth and have not yet been opened. Key Words: Phobos LIFE—Spaceflight experiments-Transpermia—Panspermia—Lithopanspermia. Astrobiology 19, 1177-1185.
\end{abstract}

\section{Introduction}

$\mathbf{L}$ IFE EITHER EMERGED in situ from prebiotic matter during Earth's Archean eon, or Earth was seeded by life that arrived here from another planet or moon. The latter hypothesis represents an idea dating back to antiquity (Sider, 1981) and experiencing a resurgence in thought more than a hundred years ago (Richter, 1865; Thomson, 1894; Arrhenius, 1903). Often, the term "panspermia" has been used in connection with the seeding scenario, but this term connotes the radiation of life throughout the Cosmos from a single, distant point. Given the prospect that short-range spread of life between planets and moons of the same star system must be easier than seeding over interstellar and intergalactic distances, other terms may be employed to connote the spread of life by meteoroids within our solar system. One such term is "transpermia," coined by Oliver Morton, circa 2000 (Morton, 2013, personal communication to D. Warmflash); we have used it in previous publications focusing particularly on transfer of life from Mars to Earth (Warmflash et al., 2007). Given the proximity of the planets of the inner Solar System, the low gravity well of Mars, and the fact that materials ejected into space move more easily from outer to inner orbits about the Sun (Kirschvink and

\footnotetext{
${ }^{1}$ The Planetary Society, Pasadena, California, USA.

${ }^{2}$ Stellar Exploration, Inc., San Luis Obispo, California, USA.

${ }^{3}$ Vector Design, Hereford, Arizona, USA.

${ }^{4}$ Space Research Institute (IKI), Moscow, Russia.

${ }^{5}$ Lomonosov Moscow State University, Moscow, Russia.

${ }^{6}$ Novozymes NA, Franklinton, North Carolina, USA.

${ }^{7}$ George Mason University, Manassas, Virginia, USA.

${ }^{8}$ German Aerospace Center (DLR e. V.), Institute of Aerospace Medicine, Radiation Biology Department, Cologne (Köln), Germany.

${ }^{9}$ Department of Environmental Science and Bioscience, Kristianstad University, Kristianstad, Sweden.

${ }^{10}$ Independent, Houston, Texas, USA.

${ }^{11}$ University of Houston, Houston, Texas, USA.

${ }^{12}$ Caltech, Pasadena, California, USA.

${ }^{13}$ Earth-Life Science Institute, Tokyo Institute of Technology, Meguro-ku, Tokyo, Japan.

${ }^{14}$ German Aerospace Center (DLR e. V.), Executive Board Division Space Research and Development, Programme Space R\&D, Cologne (Köln), Germany.

(C) Bruce H. Betts et al., 2019; Published by Mary Ann Liebert, Inc. This Open Access article is distributed under the terms of the Creative Commons Attribution Noncommercial License (http://creativecommons.org/licenses/by-nc/4.0/) which permits any noncommercial use, distribution, and reproduction in any medium, provided the original author(s) and the source are credited.
} 
Weiss, 2002), Mars-to-Earth is the life transfer scenario that is discussed most frequently (Melosh, 1985, 1988).

Whether terrestrial life could have originated on Mars depends on the ability of microorganisms to survive the voyage. The notion that loose microorganisms could escape a planet's gravity well and survive radiation and vacuum and entry through a planetary atmosphere appears tenuous. However, the concept that microorganisms could be ejected within rocks and travel successfully to another planet within those meteoroids is more plausible. Approximately one ton of martian rock ejected via major impact events arrives on Earth each year in the form of meteorites (Gladman, 1997). Many tens of meteorites have been identified as having originated in the martian crust (Nyquist et al., 2001; Meyer, 2012); this identification was confirmed by argon isotope fractionation studies using the Sample Analysis at Mars (SAM) instrument on NASA's Curiosity rover (Atreya et al., 2013). These represent only a tiny sampling of transferred martian rocks.

Although most of the interplanetary material that arrives on Earth has spent several million years in space, it is estimated that one out of $10^{7}$ Earth-impacting martian rocks has made the interplanetary journey in less than a year, and that every million years, approximately 10 rocks larger than $100 \mathrm{~g}$ are transferred from Mars to Earth in only 2-3 years (Gladman, 1997). If present within rock on Mars, microorganisms akin to those on Earth could remain viable when challenged by the pressures and heating of impact events that eject such rock into space (Mastrapa et al., 2001).

Additionally, studies of magnetic features of martian meteorites and gases trapped within suggest that interiors of such rocks are not heated to temperatures high enough to kill microorganisms during entry through Earth's atmosphere (Weiss et al., 2000, 2002; Artemieva and Ivanov, 2004; Shuster and Weiss, 2005).

Whether survival of metabolically active microbial species, or dormant spores, during the interplanetary transfer phase itself would be sufficient to allow for planetary seeding is unknown. Previously, microbial survival in space has been investigated, for periods of up to 6 years, albeit in low Earth orbit (LEO) (Horneck, 1993; Horneck et al., 1974, 1994, 2010; Reitz et al., 1995; Rettberg et al., 2002; Mancinelli, 2015) where high-energy radiation exposure is relatively low. Microbial survival also has been studied outside Earth's magnetosphere, and thus in the interplanetary radiation environment, but for relatively short durations (several days) (Buecker et al., 1973, 1975; Buecker, 1974; Horneck et al. 1974; Buecker and Horneck, 1975; Graul et al. 1975; Facius et al., 1978, 1979). The aforementioned studies, and others conducted subsequently in LEO, have demonstrated survivability of various archaea and bacteria, along with plant seeds and animals (Reitz et al., 1995; Rettberg et al., 2002; Jönsson et al., 2008; Horneck et al., 2010).

To test whether life-forms can survive the transit phase of the swift transfer scenario that occurs among a small fraction of martian ejecta, we prepared the Phobos Living Interplanetary Flight Experiment (Phobos LIFE). To take advantage of the 34 months of round-trip transit time through the space between Earth and Mars, the experiment was carried within the Russian Federal Space Agency's Phobos Sample Return spacecraft (also known as Phobos Grunt). Unfortunately, the mission failed soon after launch. We felt it was still important to document through this paper the motivation for Phobos LIFE, the science underpinning it, the technical approach and the engineering designs used. Designers of future experiments can use this information as background to test aspects of transfer of life between nearby planets and moons.

\section{Science Experiment}

Phobos LIFE carried 10 organisms, representing all three domains of life (Bacteria, Eukaryota, and Archaea) and a soil colony sample on the Phobos Grunt Sample Return flight, launched in November 2011. Spending most of the 34-month mission time in deep space, and thus outside Earth's magnetosphere, Phobos Sample Return's basketballsized return capsule would have functioned as an artificial meteoroid of sorts. The organisms flew in dried, "dormant"'-like states inside the $88 \mathrm{~g}$, patented Phobos LIFE "biomodule" (Fraze and Friedman, 2010) (Fig. 1). Since the Grunt return capsule was designed to return to Earth, the passive biomodule would have allowed for the recovery of the samples after nearly 3 years in interplanetary space. The experiment was designed to simulate weightless travel of organisms through deep space inside a meteoroid, thus protected from exposure to vacuum and with some radiation shielding, blocking all the solar ultraviolet radiation, but not enough shielding to stop much of the high-energy radiation encountered in deep space.

Regardless of who originally provided them (detailed below), all samples were shipped to the American Type Culture Collection (ATCC) facilities in Manassas, Virginia, United States, where they were sealed in individual tubes under an argon atmosphere and loaded into the Phobos LIFE biomodule. Argon was used because it is an inert gas that will not interact with the organisms. Under natural conditions on Earth, oxygen interacts with the tissues of desiccated organisms and gives rise to accumulated damage to cell components (França et al., 2007), eventually rendering the organisms nonviable, if total damage exceeds the repair capacity at rehydration. Under interplanetary transport, oxygen will not be present, so argon will provide a more representative condition for this experiment.

Upon returning from space, the samples were to be distributed among the team of investigators who had provided the samples for comparison with preflight phenotypic, genotypic, and other characteristics. Investigators would have looked for basic organism survivability as a result of the deep space voyage and also would have conducted more detailed analyses. Three Earth control biomodules were loaded with organisms from the same batch at the same time that the flight biomodule was loaded and sealed. Sealing occurred in June 2009 in preparation for the initial Phobos Sample Return mission launch date, but the mission was delayed until the launch window had passed, moving launch to 2011. One of the three control biomodules was to have been opened and organism samples analyzed shortly after the time of launch in order to determine the effects of loading and sitting on Earth for more than 2 years. A second control module was to be opened concurrently with the flight biomodule when it returned from space, and a third control was kept as backup. The spacecraft's dangerous situation was recognized soon after launch, and the decision was made to leave the control biomodules sealed. 


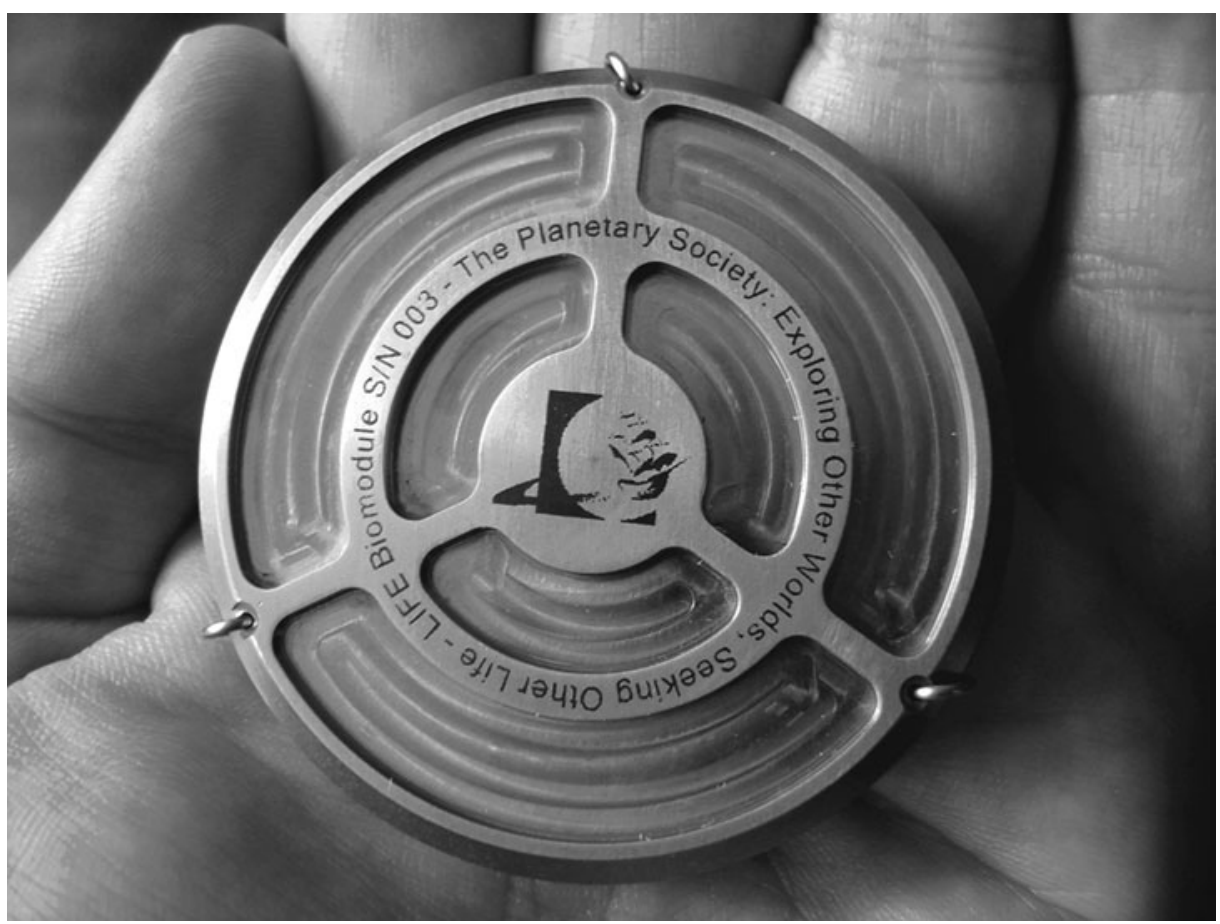

FIG. 1. Sealed Phobos LIFE biomodule. Hand for scale.

\section{The Phobos Life Biomodule}

\subsection{Requirements}

The Phobos Sample Return project required the Phobos LIFE biomodule to be (1) less than $100 \mathrm{~g}$; (2) completely passive; (3) able to survive the equivalent of a $4000 \mathrm{~g}$ (where $1 g$ is the acceleration of gravity at Earth's surface) impact without loss of structural integrity. Phobos LIFE science requirements included (1) the ability to carry small, singlestrain biological samples; (2) the ability to carry a single larger soil sample; (3) practical containers allowing effective handling, loading, and unloading; (4) the ability to seal organisms under argon; (5) redundant seals.

\subsection{Design details}

To meet the requirements, we created a container (Fig. 2) that uses webs and pockets to provide strength at low mass, and a strong, padded, multiply sealed design to provide structural integrity, with loads up to $4000 \mathrm{~g}$. Details of the biomodule's patented (Fraze and Friedman, 2010) design include the following:

The outer housing is titanium, which is both strong and lightweight. The shell is machined with "pockets" which reduce weight but do not diminish strength. The inner carrier is the polymer material Delrin, with an excellent history of space travel and many appealing properties, including ease of machining.

There are 30 Delrin tubes, each $3 \mathrm{~mm}$ in diameter, which hold the microbe samples. Unique identifying labels were placed on the top and bottom of each sample tube. Additionally, there is a central Delrin container for the soil sample.

There are several sealing mechanisms in the design. First, the lids seal to the Delrin tubes both through friction fit and

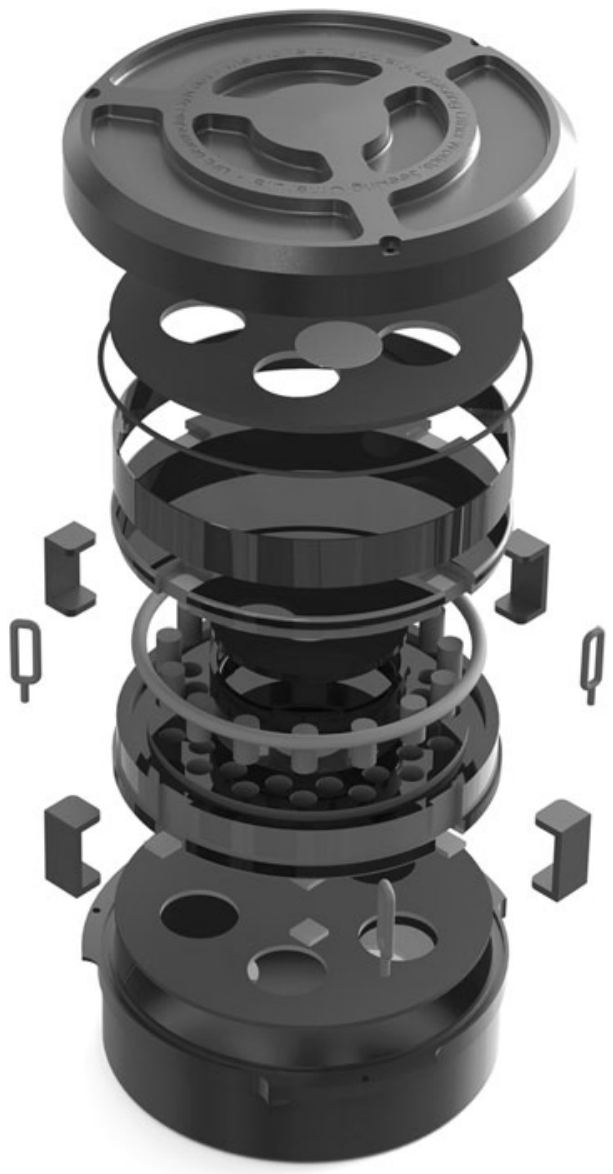

FIG. 2. Exploded view of Phobos LIFE biomodule showing components. 


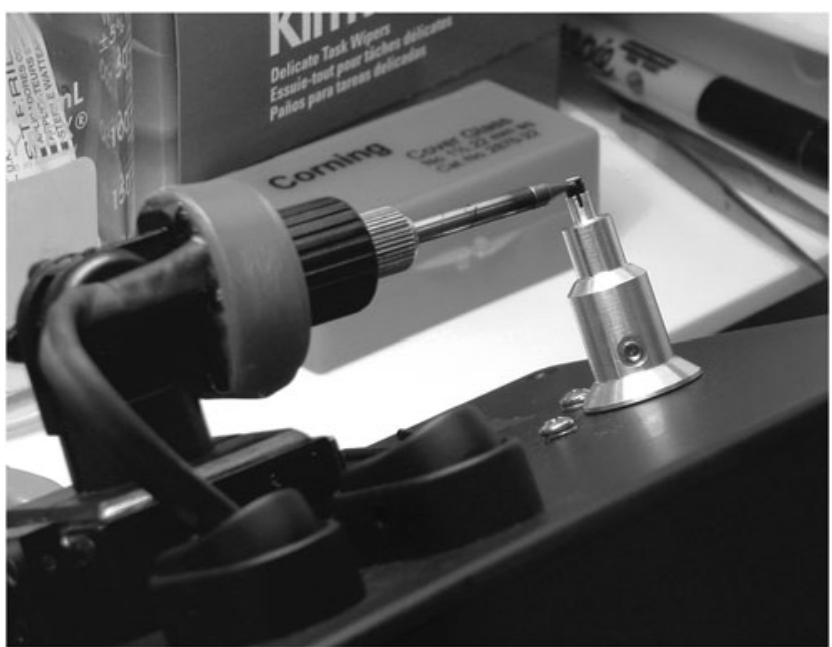

FIG. 3. Heat sealing a sample tube inside argon-filled glove box.

by welding the lids to the tubes using a custom device (Fig. 3). Additionally, the top half of the Delrin carrier presses on the sealed tubes and further prevents the lids from separating during flight.

Next, there is a silicone O-ring sandwiched between the two halves of the carrier external to the sample tubes; this polymer seal acts as a secondary seal (Fig. 4). The Delrin carrier is contained by four titanium clips which keep the two halves of the carrier under sealing pressure. These clips are also retained by Kapton tape circumferentially. The carrier has polymer pads above and below it to mitigate launch and landing shock.

The sealed and wrapped assembly is placed into the bottom half of the titanium housing; and another seal, made of indium wire, is placed in a groove between the top and bottom housings. The top is turned, engaging three integral locking lugs, which are then safety wired in place to prevent the top from backing out. The metallic indium seal is permanently crushed to seal the housing. Thus, there are several independent seals.

\subsection{Temperature and radiation detectors}

In addition to the structural components, seals, pads, and bioload, the biomodule also includes passive temperature and radiation detectors. The radiation detectors (Fig. 5) consist of eight thermoluminescence detectors (TLDs): four each of the types TLD-600 ( $\left.{ }^{6} \mathrm{LiF}: \mathrm{Mg}, \mathrm{Ti}\right)$ and TLD-700 ( $\left.{ }^{7} \mathrm{LiF}: \mathrm{Mg}, \mathrm{Ti}\right)$. They measure the absorbed dose due to ionizing radiation. Following the mission, they would have been taken into the laboratory for evaluation and determination of the doses of ionizing radiation. The same types of TLDs have been used in the framework of the MATROSHKA experiment on board the International Space Station (Reitz et al., 2009; Berger et al., 2012), as well as in the framework of the DOSIS project for radiation dosimetry on EXPOSE-E (Berger et al., 2013).

The temperature sensors (Fig. 5) were designed to determine the highest temperature incurred. For each biomodule, there were eight circular stickers (six distributed inside and two on the outside), each of which had five temperature "dots." These dots change color if a particular temperature

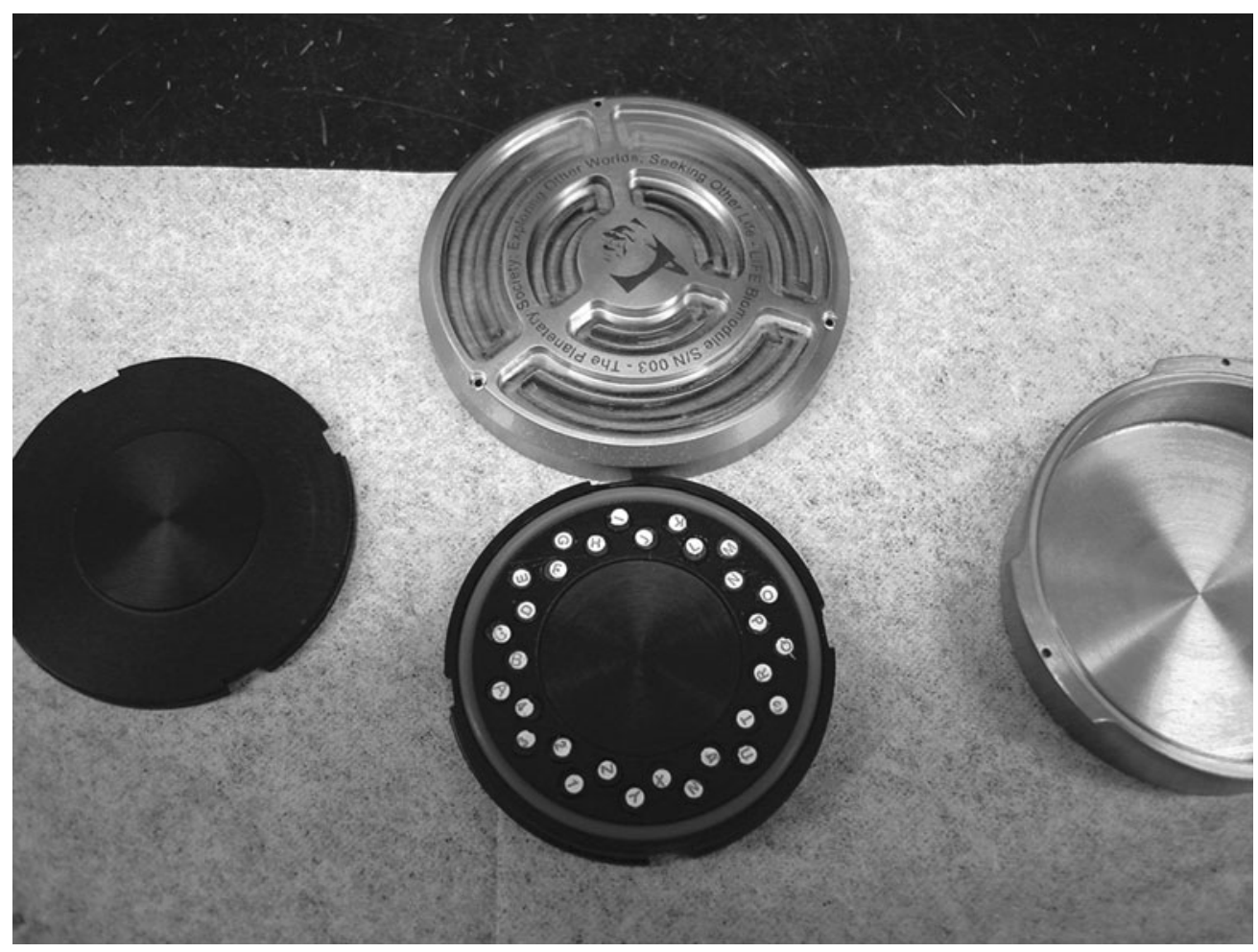

FIG. 4. Lower half of Delrin carrier (center) loaded with labeled sample tubes and central soil container. Note silicone O-ring. Also, top of carrier (left), titanium lid (top), and titanium bottom (right). 


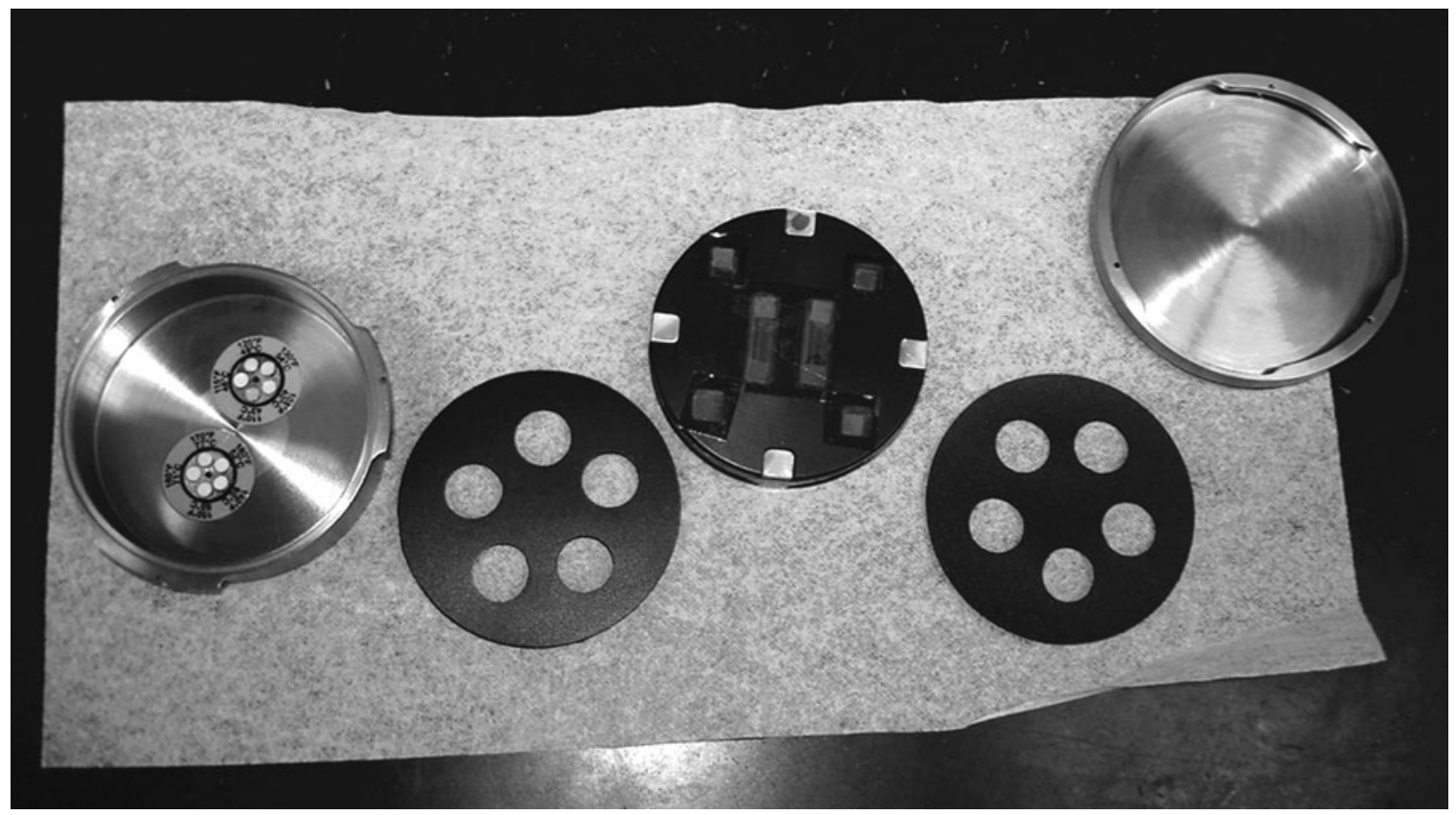

FIG. 5. Biomodule during assembly. Left to right: Titanium bottom with two temperature sensors, shock pad, bottom of loaded carrier including TLD radiation detectors (small white squares under Kapton tape), shock pad, and titanium lid.

is exceeded. Though providing limited information, these dots probably would have revealed the presence of any large thermal spikes penetrating the biomodules during the trip. Knowing this, in turn, would have influenced the interpretation of the biological sample analysis after return of the probe. The temperature stickers come in two temperature ranges giving a total range of $41-82^{\circ} \mathrm{C}$ (though we did not anticipate temperatures anywhere near the upper end of that range), and they were distributed through various locations in and on the biomodule. Additionally, one of the organisms flying was an extreme thermophile, Pyrococcus furiosus. Much of the heat resistance of this organism may depend on active processes, such as production of solutes that protect cellular proteins from denaturation. Such solutes might have been present at some level within the dormant samples of the LIFE biomodule but generally can be expected to protect only active $P$. furiosus cells (Shockley et al., 2003). Nevertheless, if only P. furiosus and the sporeforming bacteria (i.e., Bacillus subtilis and Bacillus safensis, which also are resistant to high temperatures) had survived, while all other organisms had not, this would have constituted an additional datum suggesting thermal heating far beyond what had been anticipated.

\subsection{Testing}

Many tests were carried out on engineering models of the flight biomodule identical to the flight biomodule. These included vibration tests to simulate launch vibrations, carried out at California Polytechnic State University San Luis Obispo, and impact tests, carried out at Stellar Exploration, Inc. For both tests, each of the 30 sample tubes and 1 colony sample container were filled with a fluorescent liquid. The actual flight samples are dry, but we used liquid as an extra challenging test to make sure that we could identify any leaks. The entire biomodule was sealed identically to the flight biomodule.

Vibration tests showed that the biomodule and all its components worked perfectly with no leaks, despite being subjected to vibrations beyond those that would be encountered during launch.

An air cannon was used to launch biomodules at high speeds for impact testing. Speeds and impact materials were adjusted to simulate, and exceed, parameters provided by the project, equivalent to about $4000 \mathrm{~g}$. In multiple impacts, no leaks in any seals occurred. A heat sealing mechanism was employed for the sample tubes. To make sure the heat sealing process was not detrimental to a biological payload, a series of tests was performed both with temperature sensors and with actual biological materials. The biological materials showed no ill effects, and the temperature sensors indicated minimal heating occurred in the tubes as a result of the heat sealing on the outside.

\section{The Organisms}

The organisms that flew in Phobos LIFE, and their sources, are detailed in Table 1. This set includes species from the three domains of life. There are two strains of Bacillus subtilis, both of which have a long history in spaceflight research (Horneck et al., 2010). The organisms used in the 30 sample tubes meet the following criteria determined by the Phobos LIFE science team:

- There are representatives of all three domains of life (Bacteria, Archaea, and Eukaryota).

- All are nonpathogenic to humans and animals.

- Most have been flown previously in LEO.

- All are very well characterized, most with sequenced genomes.

- Most are extremophiles or extremely robust. 
Table 1. Phobos Life Organisms

\begin{tabular}{|c|c|c|c|c|}
\hline Organism & $\begin{array}{l}\text { ATCC reference } \\
\text { number }\end{array}$ & Type of sample & Form & Organism provided by \\
\hline Bacillus safensis $\mathrm{f036b}$ & ATCC $^{\circledR}$ BAA- $1126^{\mathrm{TM}}$ & Bacteria & Freeze-dried & $\begin{array}{l}\text { ATCC, Dr. Tim Lilburn } \\
\text { et al., USA }\end{array}$ \\
\hline Bacillus subtilis 168 & ATCC $^{\circledR} 23857^{\mathrm{TM}}$ & Bacteria & $\begin{array}{l}\text { Freeze-dried (ATCC) } \\
\text { and air-dried } \\
\text { spores (DLR) }\end{array}$ & $\begin{array}{l}\text { ATCC (1 tube), Dr. Tim } \\
\text { Lilburn } \text { et al., USA, and } \\
\text { DLR ( } 2 \text { tubes), Dr. Petra } \\
\text { Rettberg } \text { et al., Germany }\end{array}$ \\
\hline Bacillus subtilis MW01 & $\begin{array}{l}\text { No DLR ref number } \\
\text { (Wassmann et al., } \\
\text { 2010, 2011) }\end{array}$ & Bacteria & Air-dried spores & $\begin{array}{l}\text { DLR, Dr. Petra Rettberg } \\
\text { et al., Germany }\end{array}$ \\
\hline Deinococcus radiodurans $\mathrm{R} 1$ & $\mathrm{ATCC}^{\circledR}$ BAA- $816^{\mathrm{TM}}$ & Bacteria & Freeze-dried & $\begin{array}{l}\text { ATCC, Dr. Tim Lilburn } \\
\text { et al., USA }\end{array}$ \\
\hline $\begin{array}{l}\text { Saccharomyces cerevisiae } \\
\text { strain W303 }\end{array}$ & $\mathrm{ATCC}^{\circledR} 200060^{\mathrm{TM}}$ & Yeast & Freeze-dried & $\begin{array}{l}\text { ATCC, Dr. Tim Lilburn } \\
\text { et al., USA }\end{array}$ \\
\hline Arabidopsis thaliana & & Seeds & Seeds & $\begin{array}{l}\text { Dr. David Warmflash, } \\
\text { USA; original source: } \\
\text { Arabidopsis Biological } \\
\text { Resource Center } \\
\text { (ABRC), Ohio State } \\
\text { University }\end{array}$ \\
\hline Milnesium tardigradum & & Animals & Air-dried & $\begin{array}{l}\text { Kristianstad University, } \\
\text { Dr. Ingemar Jönsson, } \\
\text { Sweden }\end{array}$ \\
\hline Richtersius coronifer & & Animals & Air-dried & $\begin{array}{l}\text { Kristianstad University, } \\
\text { Dr. Ingemar Jönsson, } \\
\text { Sweden }\end{array}$ \\
\hline Echiniscus testudo & & Animals & Air-dried & $\begin{array}{l}\text { Kristianstad University, } \\
\text { Dr. Ingemar Jönsson, } \\
\text { Sweden }\end{array}$ \\
\hline Haloarcula marismortui & ATCC $^{\circledR} 43049^{\mathrm{TM}}$ & Archaea & Air-dried with salt & $\begin{array}{l}\text { ATCC, Dr. Tim Lilburn } \\
\text { et al., USA }\end{array}$ \\
\hline Pyrococcus furiosus & $\begin{array}{l}\text { ATCC }^{\circledR} 43587^{\mathrm{TM}} \\
(\text { DSM-3638) }\end{array}$ & Archaea & Freeze-dried & $\begin{array}{l}\text { ATCC, Dr. Tim Lilburn } \\
\text { et al., USA }\end{array}$ \\
\hline Methanothermobacter wolfeii & $\mathrm{ATCC}^{\circledR} 43096^{\mathrm{TM}}$ & Archaea & Air-dried & $\begin{array}{l}\text { ATCC, Dr. Tim Lilburn } \\
\text { et al., USA }\end{array}$ \\
\hline Soil microbial community & & Arid soil & Air-dried & $\begin{array}{l}\text { Moscow State University, } \\
\text { Dr. Elena Vorobyova, } \\
\text { Russia }\end{array}$ \\
\hline
\end{tabular}

- All are in dormant states (inactive, nonreplicating) while packaged within the biomodules: some are dormant as endospores, some are seeds (Arabidopsis thaliana), while others have been otherwise desiccated in the laboratory.

- Each organism sample consisted of a distinct species, or strain, stored in three tubes. The exceptions were the tardigrades; these also occupied three tubes, but each tube contained a mixture of three tardigrade species.

The soil sample in the center of the biomodule (arid soil from the Negev Desert, Israel) contained a native soil microbial community, based on indications that colonies of different kinds of organisms may have enhanced survival abilities in situ (Vorobyova et al., 1997; Soina and Vorobyova, 2004; Gilichinsky et al., 2007; Tarlera et al., 2008, Shade et al., 2013). Air-dried bacteria and archaea were dried in a sterile environment in the Delrin sample tubes. Freeze-dried archaea and bacteria were taken directly from storage tubes. The freeze-dried pellets of cells were broken up and loaded into the Delrin sample tube (Fig. 6), and the amount added was weighed.

\section{Shuttle LIFE}

A related experiment, Shuttle LIFE, flew on space shuttle mission STS-134 in May 2011. A subset of the Phobos LIFE organisms, B. subtilis MW01, D. radiodurans R1, P. furiosus, H. marismortui, and two species of tardigrades (Richtersius coronifer and Macrobiotus cf. hufelandi, the latter of which actually was not part of Phobos LIFE), were flown in the same Delrin sample tubes used for Phobos LIFE. Rather than placing the organism-loaded Delrin sample tubes inside a discoid biomodule, however, the tubes used in Shuttle LIFE were inserted into larger tubes as part of the CREST-1 commercial payload. Shuttle LIFE was to serve as a dry run for Phobos LIFE operational procedures. Additionally, the science provided from the organisms in LEO would have been used for comparison with results of Phobos LIFE. Since they 


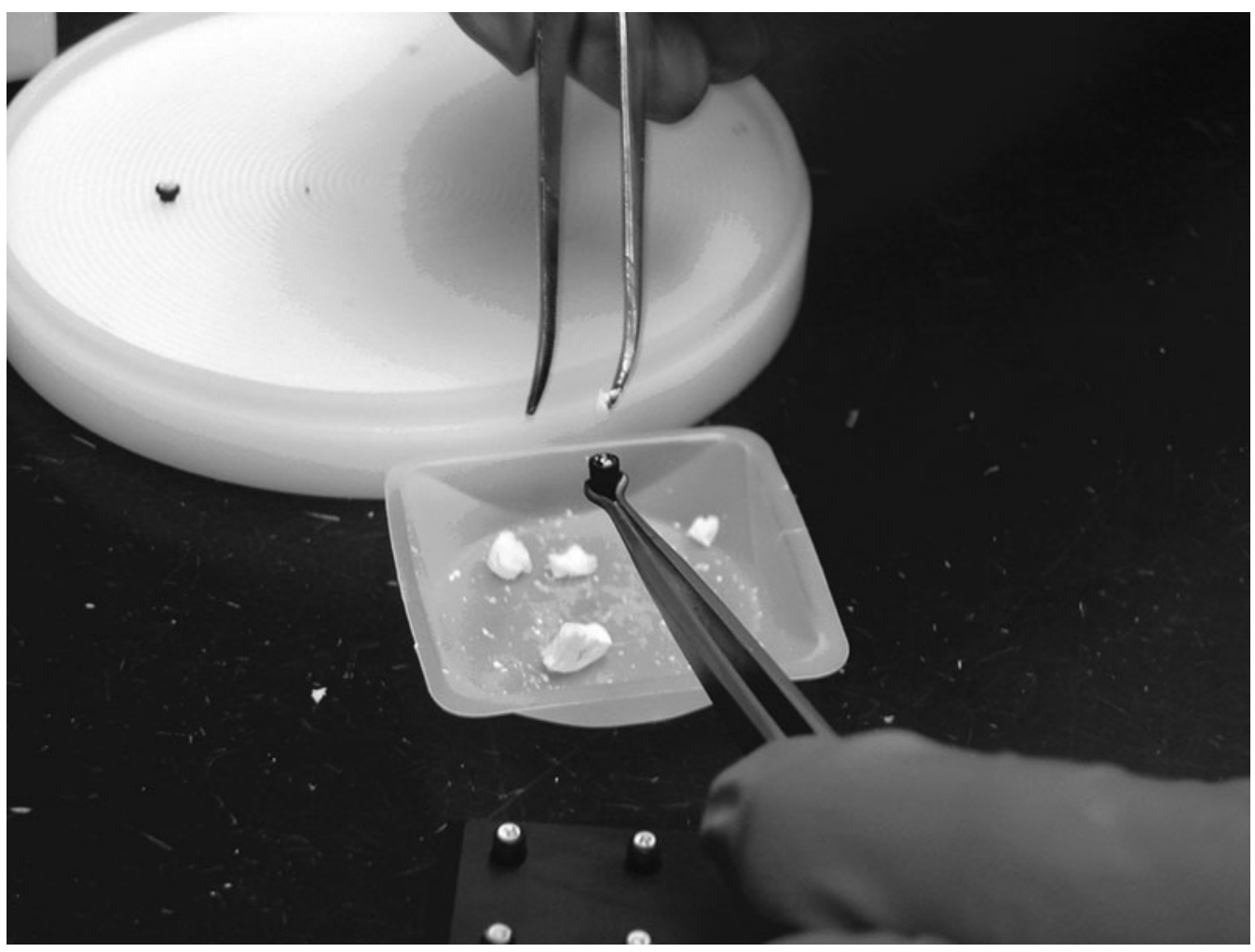

FIG. 6. Loading freeze-dried organisms into Phobos LIFE sample tube.

also may be useful for any new LIFE experiments on upcoming deep space missions, we are preparing for publication the Shuttle LIFE postflight results.

\section{Study of Life on the Asteroid Redirect Mission and the Future}

As part of a NASA Asteroid Redirect Mission (ARM) Broad Agency Announcement, NASA selected a Planetary Society study of accommodating LIFE on ARM. The concept was to fly one or more LIFE biomodules near the exterior of the ARM robotic spacecraft. Then, a few years later, when astronauts traveled to the retrieved piece of an asteroid, they would also remove the LIFE biomodule (or biomodules) for return to Earth. This would have achieved the core science goal of Phobos LIFE of flying organisms in a simulated meteoroid in deep space for several years then returning them to Earth for analysis.

The ARM LIFE study (Betts and Friedman, 2015) found that LIFE could be accommodated on ARM and returned by astronauts. The accommodation was found to be relatively easy and could meet the safety requirements of being retrieved by astronauts. LIFE, in part due to its rugged, flighttested design, would place very few requirements on the ARM or the crewed mission. Requirements would include placing the biomodule near or on the surface of the spacecraft to avoid high radiation shielding or amplification effects, and keeping the biomodules at a temperature less than $40^{\circ} \mathrm{C}$, though very brief higher external temperature spikes could occur as long as the biological samples would not incur significant temperature spikes. For the astronaut retrieval, easy access would also be required, as well as pos- sibly a tether. Two possible nominal test accommodations were found, one inside and one outside the ARM toolbox that would carry tools for future astronauts.

ARM LIFE was formally proposed to fly on the ARM mission, but the ARM mission was cancelled before selections were made. Though the ARM mission was cancelled, the ARM LIFE accommodation studies illustrated the flexibility of the LIFE biomodule for flying on a variety of missions. The LIFE team is still very interested in flying on future deep space sample returns. We continue to pursue possibilities.

\section{Conclusions}

Phobos LIFE on the Phobos Sample Return (Grunt) mission would have provided the first study of organism survival after deep space flight beyond Earth's magnetosphere for more than a few days. Although the Phobos Grunt mission failed before reaching deep space, Phobos LIFE can serve as a model for future deep space sample return missions. We are studying flying LIFE on possible future sample return missions. Using the same LIFE biomodule design, or a similar design, such missions may provide new insights into the plausibility of the short transfer of life over relatively small interplanetary distances by testing survivability during transport through deep space inside a simulated meteoroid.

More information on the LIFE experiments can be found at http://planetary.org/programs/projects/life/

\section{Acknowledgments}

Our Phobos LIFE Team member, colleague, and friend, David S. McKay, PhD, passed away in February 2013. We 
wish to acknowledge his contributions to this project and to the team. This project was made possible by the generous support of members of The Planetary Society. We thank ATCC, where authors T.L. and A.S. worked, for all their contributions to the LIFE projects. We thank Guenther Reitz for his assistance. We also thank the many individuals and organizations who made up the Phobos Sample Return project, in particular Alexander Zakharov and Viacheslav Linkin.

\section{Author Disclosure Statement}

No competing financial interests exist.

\section{References}

Arrhenius, S. (1903) Die Verbreitung des Lebens im Weltenraum. Umschau 7:481-485.

Artemieva, N.A. and Ivanov, B.A. (2004) Launch of martian meteorites in oblique impacts. Icarus 171:183-196.

Atreya, S.K., Trainer, M.G., Franz, H.B., Wong, M.H., Manning, H.L.K., Malespin, C.A., Mahaffy, P.R., Conrad, P.G., Brunner, A.E., Leshin, L.A., Jones, J.H., Webster, C.R., Owen, T.C., Pepin, R.O., and Navarro-González, R. (2013) Primordial argon isotope fractionation in the atmosphere of Mars measured by the SAM instrument on Curiosity, and implications for atmospheric loss. Geophys Res Lett 40:56055609.

Berger, T., Hajek, M., Bilski, P., Koerner, C., Vanhavere, F., and Reitz, G. (2012) Cosmic radiation exposure of biological test systems during the EXPOSE-E mission. Astrobiology 12 : 387-392.

Berger, T., Bilski, P., Hajek, M., Puchalska, M., and Reitz, G. (2013) The MATROSHKA experiment: results and comparison from EVA (MTR-1) and IVA (MTR-2A/2B) exposure. Radiat Res 180:622-637.

Betts, B.H. and Friedman, L.D. (2015, January 13) Accommodating the living interplanetary flight experiment on the Asteroid Retrieval Mission. Available online at http:// planetary.s3.amazonaws.com/assets/pdfs/Betts-TPS-ARMLIFE-Final-Briefing-20150113.pdf

Buecker, H. (1974) The Biostack experiments I and II aboard Apollo 16 and 17. Life Sci Space Res 12:43-50.

Buecker, H. and Horneck, G. (1975) The biological effectiveness of HZE-particles of cosmic radiation studied in the Apollo 16 and 17 Biostack experiments. Acta Astronaut 2: 247-264.

Buecker, H., Horneck, G., Allkofer, O.C., Bartholoma, K.P., Beaujean, R., Cuer, P., Enge, W., Facius, R., Francois, H., Graul, E.H., Henig, G., Heinrich, W., Kaiser, R., Kuhn, H., Massue, J.P., Planel, H., Portal, G., Reinholz, E., Ruther, W., Scheuermann, W., Schmitt, R., Schopper, E., Schott, J.U., Soleilhavoup, J.P., and Wollenhaupt, H. (1973) The Biostack experiment on Apollo 16. Life Sci Space Res 11:295-305.

Buecker, H., Facius, R., Hildebrand, D., and Horneck, G. (1975) Results of the Bacillus subtilis unit of the Biostack II experiment: physical characteristics and biological effects of individual cosmic HZE particles. Life Sci Space Res 13:161166.

Facius, R., Buecker, H., Hildebrand, D., Horneck, G., Holtz, G., Reitz, G., Schafer, M., and Toth, B. (1978) Radiobiological results from the Bacillus subtilis Biostack experiments within the Apollo and the ASTP space flights. Life Sci Space Res 16: $151-156$.
Facius, R., Buecker, H., Horneck, G., Reitz, G., and Schafer, M. (1979) Dosimetric and biological results from the Bacillus subtilis Biostack experiment with the Apollo-Soyuz Test Project. Life Sci Space Res 17:123-128.

França, M.B., Panek, A.D., and Eleutherio, E.C.A. (2007) Oxidative stress and its effects during dehydration. Comp Biochem Physiol Part A 146:621-631.

Fraze, R. and Friedman, L. (2010) U.S. Patent No. 7,753,207: Living Interplanetary Flight Experimental Capsule. The Planetary Society, Pasadena, CA.

Gilichinsky, D.A., Wilson, G.S., Friedmann, E.I., McKay, C.P., Sletten, R.S., Erokhina, L.G. Fyodorov-Davydov, D.G., Hallet, B., Ivanushkina, N.E., Kochkina, G.A., Laurinavichyus, K.S., Ozerskaya, S.M., Rivkina, E.M., Shatilovich, A.V., Shcherbakova, V.A., Soina, V.S., Sorokovikov, V.A., Spirina, E.V., Tiedje, J.M., Vishnivetskaya, T.A., and Vorobyova, E.A. (2007) Microbial populations in Antarctic permafrost. Astrobiology 7:275-311.

Gladman. B. (1997) Destination Earth: martian meteorite delivery. Icarus 130:228-246.

Graul, E.H., Ruther, W., Heinrich, W., Allkofer, O.C., Kaiser, R., Pfohl, R., Schopper, E., Henig, G., Schott, J.U., and Buecker, H. (1975) Radiobiological results of the Biostack experiment on board Apollo 16 and 17. Life Sci Space Res 13: 153-159.

Horneck, G. (1993) Responses of Bacillus subtilis spores to space environment: results from experiments in space. Orig Life Evol Biosph 23:37-52.

Horneck, G., Facius, R., Enge, W., Beaujean, R., and Bartholoma, K.P. (1974) Microbial studies in the Biostack experiment of the Apollo 16 mission: germination and outgrowth of single Bacillus subtilis spores hit by cosmic HZE particles. Life Sci Space Res 12:75-83.

Horneck, G., Buecker, H., and Reitz, G. (1994) Long-term survival of bacterial spores in space. Adv Space Res 14:41-45.

Horneck, G., Klaus, D.M., and Mancinelli, R.L. (2010) Space microbiology. Microbiol Mol Biol Rev 74:121-156.

Jönsson, K.I., Rabbow, E., Schill, R.O., Harms-Ringdahl, M., and Rettberg, P. (2008) Tardigrades survive exposure to space in low Earth orbit. Curr Biol 18:R729-R731.

Kirschvink, J.L. and Weiss, B.P. (2002) Mars, panspermia, and the origin of life: where did it all begin? Palaeontol Electronica 4:8-15.

Mancinelli, R.L. (2015) The affect of the space environment on the survival of Halorubrum chaoviator and Synechococcus (Nägeli): data from the Space Experiment OSMO on EXPOSE-R. Int J Astrobiol 14:123-128.

Mastrapa, R.M.E., Glanzberg, H., Head, J.N., Melosh, H.J., and Nicholson, W.L. (2001) Survival of bacteria exposed to extreme acceleration: implications for panspermia. Earth Planet Sci Lett 189:1-8.

Melosh, H.J. (1985) Ejection of rock fragments from planetary bodies. Geology 13:144-148.

Melosh, H.J. (1988) The rocky road to panspermia. Nature 332: 687-688.

Meyer, C. (2012) Mars Meteorite Compendium, NASA, Houston. Nyquist, L.E., Bogard, D.D., Shih, C.Y., Greshake, A., Stöfler, D., and Eugster, O. (2001) Ages and geologic histories of martian meteorites. Space Sci Rev 96:105-164.

Reitz, G., Horneck, G., Facius, R., and Schafer, M. (1995) Results of space experiments (review of entire Biostack program). Radiat Environ Biophys 34:139-144.

Reitz, G., Berger, T., Bilski, P., Facius, R., Hajek, M., Petrov, V., Puchalska, M., Zhou, D., Bossler, J., Akatov, Y., Shurshakov, 
V., Olko, P., Ptaszkiewicz, M., Bergmann, R., Fugger, M., Vana, N., Beaujean, R., Burmeister, S., Bartlett, D., Hager, L., Pálfalvi, J., Szabó, J., O’Sullivan, D., Kitamura, H., Uchihori, Y., Yasuda, N., Nagamatsu, A., Tawara, H., Benton, E., Gaza, R., McKeever, S., Sawakuchi, G., Yukihara, E., Cucinotta, F., Semones, E., Zapp, N., Miller, J., and Dettmann, J. (2009) Astronaut's organ doses inferred from measurements in a human phantom outside the International Space Station. Radiat Res 171:225-235.

Rettberg, P., Eschweiler, U., Strauch, K., Reitz, G., Horneck, G., Wanke, H., Brack, A., and Barbier, B. (2002) Survival of microorganisms in space protected by meteorite material: results of the experiment 'EXOBIOLOGIE' of the PERSEUS mission. Adv Space Res 30:1539-1545.

Richter, H. (1865) Zur Darwinschen Lehre. Schmidts Jahrb Ges Med 126:243-249.

Shade, A., Caporaso, J.G., Handelsman, J., Knight, R., and Fierer, N. (2013) A meta-analysis of changes in bacterial and archaeal communities with time. ISME J 7:1493-1506.

Shockley, K.R., Ward, D.E., Chhabra, S.R., Conners, S.B., Montero, C.I., and Kelly, R.M. (2003) Heat shock response by the hyperthermophilic archaeon Pyrococcus furiosus. Appl Environ Microbiol 69:2365-2371.

Shuster, D.L. and Weiss, B.P. (2005) Martian surface paleotemperatures from thermochronology of meteorites. Science 309:594-597.

Sider, D. (1981) The Fragments of Anaxagoras, edited with an introduction and commentary, Beiträge zur klassischen Philologie 118, Anton Hain, Meisenheim am Glan, Germany.

Soina, V.S. and Vorobyova, E.A. (2004) Adaptation of bacteria to the terrestrial permafrost environment: a biomodel for astrobiology. In Origins: Genesis, Evolution and Biodiversity of Life, edited by J. Seckbach, Kluver Academic Publishers, Dordrecht, the Netherlands, pp 427-444.

Tarlera, S., Jangid, K., Ivester, A.H., Whitman, W.B., and Williams, M.A. (2008) Microbial community succession and bacterial diversity in soils during 77,000 years of ecosystem development. FEMS Microbiol Ecol 64:129-140.

Thomson, W. (1894) 1871 presidential address to the British Association. In Popular Lectures and Addresses, MacMillan and Co., New York, pp 132-205.

Vorobyova, E., Soina, V., Gorlenko, M., Minkovskaya, N., Zalinova, N., Mamukelashvili, A., Gilichinsky, D., Rivkina, E., and Vishnivetskaya, T. (1997) The deep cold biosphere: facts and hypothesis. FEMS Microbiol Rev 20:277-290.
Warmflash, D., Ciftcioglu, N., Fox, G.E., McKay, D.S., Friedman, L., Betts, B., and Kirschvink, J. (2007) Living Interplanetary Flight Experiment (LIFE): an experiment on the survivability of microorganisms during interplanetary transfer [\#7043]. In First International Conference on the Exploration of Phobos and Deimos, Lunar and Planetary Institute, Houston, LPI Contribution 1377.

Wassmann, M., Moeller, R., Reitz, G., and Rettberg, P. (2010) Adaptation of Bacillus subtilis cells to Archean-like UV climate: relevant hints of microbial evolution to remarkably increased radiation resistance. Astrobiology 10:605-615.

Wassmann, M., Moeller, R., Reitz, G., and Rettberg, P. (2011) Growth phase-dependent UV-C resistance of Bacillus subtilis: data from a short-term evolution experiment. Arch $\mathrm{Mi}$ crobiol 193:823-832.

Weiss, B.P., Kirschvink, J.L., Baudenbacher, F.J., Vali, H., Peters, N.T., Macdonald, F.A., and Wikswo, J.P. (2000) A low temperature transfer of ALH84001 from Mars to Earth. Science 290:791-795.

Weiss, B.P., Shuster, D.L., and Stewart, S.T. (2002) Temperatures on Mars from ${ }^{40} \mathrm{Ar} /{ }^{39} \mathrm{Ar}$ thermochronology of ALH84001. Earth Planet Sci Lett 201:465-472.

Address correspondence to: Bruce Betts The Planetary Society 60 South Los Robles Avenue Pasadena, CA 91101

E-mail: bruce.betts@planetary.org

Submitted 14 May 2018 Accepted 14 December 2018

$\begin{aligned} & \text { Abbreviations Used } \\ & \text { ARM }=\text { Asteroid Redirect Mission } \\ & \text { ATCC }=\text { American Type Culture Collection } \\ & \text { LEO }=\text { low Earth orbit } \\ & \text { LIFE }=\text { Living Interplanetary Flight Experiment } \\ & \text { TLDs }=\text { thermoluminescence detectors }\end{aligned}$

